Board of Governors of the Federal Reserve System

International Finance Discussion Papers

Number 1308

January 2021

\title{
The Financial (In)Stability Real Interest Rate, $\mathbf{R}^{* *}$
}

Ozge Akinci, Gianluca Benigno, Marco Del Negro, and Albert Queralto

Please cite this paper as:
Akinci, Ozge, Gianluca Benigno, Marco Del Negro, and Albert Queralto (2021).
"The Financial (In)Stability Real Interest Rate, R**," International Finance Discus-
sion Papers 1308. Washington: Board of Governors of the Federal Reserve System,
https://doi.org/10.17016/IFDP.2021.1308.

NOTE: International Finance Discussion Papers (IFDPs) are preliminary materials circulated to stimulate discussion and critical comment. The analysis and conclusions set forth are those of the authors and do not indicate concurrence by other members of the research staff or the Board of Governors. References in publications to the International Finance Discussion Papers Series (other than acknowledgement) should be cleared with the author(s) to protect the tentative character of these papers. Recent IFDPs are available on the Web at www.federalreserve.gov/pubs/ifdp/. This paper can be downloaded without charge from the Social Science Research Network electronic library at www.ssrn.com. 


\title{
The Financial (In)Stability Real Interest Rate, $\mathrm{R}^{* *}$
}

\author{
Ozge Akinci, Gianluca Benigno, Marco Del Negro and Albert Queralto
}

December 30, 2020

\begin{abstract}
We introduce the concept of financial stability real interest rate using a macroeconomic banking model with an occasionally binding financing constraint as in Gertler and Kiyotaki (2010). The financial stability interest rate, $\mathrm{r}^{* *}$, is the threshold interest rate that triggers the constraint being binding.

Increasing imbalances in the financial sector measured by an increase in leverage are accompanied by a lower threshold that could trigger financial instability events. We also construct a theoretical implied financial condition index and show how it is related to the gap between the natural and financial stability interest rates.
\end{abstract}

Key words: $\mathrm{r}^{* *}$, financial crises, financial stability, occasionally binding credit constraint JEL classification: E4, E5, G0

\section{Introduction}

One of the key aspects that has characterized the global economy and in particular advanced economies in the last two decades is the secular decline in real interest rates. The decline in global real interest rates has largely occurred in a context of relatively low and stable inflation suggesting that the drop in observed real interest rates reflects a fall in what researchers refer to as the "natural real interest rate," also known as r* (see, for example, Holston et al., 2017, and Del Negro et al., 2019). The concept of natural real interest rate dates to Wicksell (1898) and it is usually defined as the "real rate consistent with real GDP equals to its potential in the absence of shocks to demand. In turn potential GDP is defined to be the level of output consistent with stable price inflation absent transitory supply shocks" (see Laubach and Williams (2003)). In short, the concept of natural real interest rate is associated with the notion of macroeconomic stability.

In this paper we propose a complementary concept that we call the "financial stability real interest rate, $\mathrm{r}^{* *}$." The core idea relies on determining the underlying level of real interest rate that might generate financial instability dynamics. Both conceptually and observationally $\mathrm{r}^{* *}$ differs from the "natural real interest rate" and from the observed real interest rate reflecting a tension in terms of macroeconomic stabilization versus financial stability objectives.

First, we discuss $\mathrm{r}^{* *}$ from a conceptual standpoint. To define the financial stability real interest rate one first needs to develop a concept of financial stability. To this end, we consider an environment 
in which some agents in the economy face a credit constraint that gives rise to debt-deflation or asset fire-sale dynamics. Importantly, the credit constraint is occasionally binding. This implies that the economy is characterized by two states: when the constraint is not binding the economy is in a normal state or tranquil period; when the constraint binds the economy is in a crisis mode and a financial instability dynamic arises. The financial stability real interest rate is the interest rate that, for a given state of the economy (for example for a given amount of private debt), would be consistent with the constraint being just binding.

Just like the natural rate of interest provides a benchmark for monetary policy in terms of macroeconomic stability, $\mathrm{r}^{* *}$ is meant to provide a benchmark for financial stability: if the real rate in the economy is at or above $\mathrm{r}^{* *}$, the tightness of financial conditions may generate financial instability. Like the natural interest rate, the financial (in)stability real interest rate is state dependent: it evolves with the conditions of the economy, and in particular with the degree of imbalances in the financial system. Along a path of higher external debt and lower net worth, higher leverage of the banking sector is accompanied by lower $\mathrm{r}^{* *}$. This might suggest that increasing the real interest rate might create episodes of financial turbulence.

The notion of a financial (in)stability real interest rate broadly applies to any model where the economy fluctuates between normal state and a crisis state (see for example Mendoza (2010), Benigno et al. (2013), and Akinci and Chahrour (2018) in the context of the sudden stop literature). For concreteness, in this paper we use a particular model to illustrate how $\mathrm{r}^{* *}$ is constructed. The specific approach that we will follow in developing the concept of the financial stability real interest rate builds upon the banking framework developed by Gertler and Karadi (2011) and Gertler and Kiyotaki (2015). One of the virtues of using the the Gertler-Kiyotaki framework is that it allows to relate the concept of financial stability real interest rate also to key variables for financial intermediaries such as the net worth or the asset/liability ratio.

In this framework, financial intermediaries channel funds from households to firms. The key imperfection is that banks have a limit in their ability to raise funds because of a moral hazard problem. It is assumed that after raising funds and buying assets at the beginning of the period, and then the banker decides whether to operate honestly or divert assets for personal use. This moral hazard problem gives rise to an incentive compatibility constraint that creates a link between the value of the bank and the value of the assets that can be diverted.

In their seminal work, Gertler and Karadi (2011) and Gertler and Kiyotaki (2015) always assume that the constraint is binding. The key departure that we would like to consider, as in Akinci and Queralto (forthcoming), is to allow for the constraint to be occasionally binding so that the economy can display both a tranquil and a crisis state. This departure requires using a global solution method for solving the model and takes into account the non-linearity generated by the occasionally binding constraint.

As a first pass we focus on a version of the model in which there is no need to determine nominal variables as contracts are expressed in real terms. Therefore by construction the real rate in this economy coincides with the natural rate of interest $r^{*}$, that is, the underlying interest rate consistent with macroeconomic stability. In order to further simplify the exposition, in this paper we illustrate the mechanism in a situation where the real interest rate is exogenous as, for example, in a small 
open economy. We leave the discussion of the rich interactions between monetary policy and the financial (in)stability real interest rate to further research.

\section{The model}

We propose a framework that builds upon the banking model developed in Gertler and Kiyotaki (2010). In this setting, banks make risky loans to nonfinancial firms and collect deposits from both domestic households and foreigners. Because of an agency problem, banks may be constrained in their access to external funds. The key aspect for the purpose of our analysis is to allow for this constraint to be occasionally binding, as in Akinci and Queralto (forthcoming). In normal, or "tranquil," times, banks' constraints do not bind: credit spreads are small and the economy's behavior is similar to a frictionless neoclassical framework. When the constraint binds the economy enters into financial crisis mode: credit spreads rise sharply, and investment and credit collapse, consistent with the evidence.

As we mentioned above for simplicity at this stage we consider a real model in which there is no nominal determination.

\section{$2.1 \quad$ Households}

Each household is composed of a constant fraction $(1-f)$ of workers and a fraction $f$ of bankers. Workers supply labor to the firms and return their wages to the household. Each banker manages a financial intermediary ("bank") and similarly transfers any net earnings back to the household. Within the family there is perfect consumption insurance.

Households do not hold capital directly. Rather, they deposit funds in banks. The deposits held by each household are in intermediaries other than the one owned by the household. Bank deposits are riskless one-period securities. Consumption, $C_{t}$, bond holdings, $B_{t}$, and labor decisions, $H_{t}$, are given by maximizing the discounted expected future flow of utility

$$
\mathbb{E}_{t} \sum_{i=0}^{\infty} \beta^{i} U\left(C_{t+i}, H_{t+i}\right)
$$

subject to the budget constraint $C_{t}+B_{t} \leq W_{t} H_{t}+R_{t-1} B_{t-1}+\Pi_{t} \forall t$.

$\mathbb{E}_{t}$ denotes the mathematical expectation operator conditional on information available at time $t$, and $\beta \in(0,1)$ represents a subjective discount factor. The variable $W_{t}$ is the real wage, $R_{t}$ is the (gross) real interest rate received from holding the one-period deposit, and $\Pi_{t}$ is total profits distributed to households from their ownership of both banks and firms.

\subsection{Banks}

Banks are owned by the households and operated by the bankers within them. In addition to its own equity capital, a bank can obtain external funds from both domestic households, $b_{t}$, and an external sector, $b_{t}^{*}$, such that total external financing available to the bank is given by $d_{t}=b_{t}+b_{t}^{*}$. 
We assume that both domestic deposits and external borrowing are one-period non-contingent debt. Thus, by arbitrage their returns need to be equalized in equilibrium, a condition we impose at the onset 1

In addition, banks in period $t$ can raise an amount $e_{t}$ of new equity. The new equity is available in the following period to make risky loans to nonfinancial firms, together with the equity accumulated via retained earnings and with external financing. Accordingly, in each period the bank uses its net worth $n_{t}$ (which includes equity raised in the previous period) and external funds $d_{t}$, to purchase securities issued by nonfinancial firms, $s_{t}$, at price $Q_{t}$. In turn, nonfinancial firms use the proceeds to finance their purchases of physical capital.

\subsubsection{Agency Friction and Incentive Constraint}

We follow Gertler and Kiyotaki (2010) in assuming that banks are "specialists" who are efficient at evaluating and monitoring nonfinancial firms and at enforcing contractual obligations with these borrowers. For this reason firms rely solely on banks to obtain funds and there are no contracting frictions between banks and firms. However, as in Gertler and Kiyotaki (2010), we introduce an agency problem whereby the banker managing the bank may decide to default on its obligations and instead transfer a fraction of assets to the households, in which case it is forced into bankruptcy and its creditors can recover the remaining funds. In recognition of this possibility, creditors potentially limit the funds they lend to banks. In our setup, banks may or may not be credit constrained, depending on whether or not they are perceived to have incentives to disregard their contractual obligations.

More specifically, after having borrowed external funds but before repaying its creditors, the bank may decide to default on its obligations and divert fraction $\theta$ of risky loans. In this case, the bank is forced into bankruptcy and its creditors recover the remaining funds. To ensure that the bank does not divert funds, the incentive constraint must hold:

$$
V_{t} \geq \theta Q_{t} s_{t}
$$

where $V_{t}$ stands for the continuation value of the bank. This constraint requires that the bank's continuation value be higher than the value of the diverted funds. Section 2.2 .3 below describes in detail the bank's budget constraint and balance sheet identity.

\subsubsection{Equity Issuance}

One of the key features of our model is that banks are allowed to raise new equity each period from the households they belong to, provided that they survive into the following period. As is standard in the literature, we assume that a banker continues its business only with iid probability $\sigma$. With the complementary probability a banker exits, transfers retained earnings to the household, and becomes a worker in period $t+1$. Banker exit can be seen as a simple way to capture dividend payouts to the household, and is useful in allowing a realistic calibration of the model's steady state.

\footnotetext{
${ }^{1}$ We denote banks' individual variables with lowercase letters, and later use uppercase to refer to their aggregate counterparts.
} 
At the end of period $t$, surviving banks have the option to raise new equity, $e_{t}$ from the household, which will be available in $t+1$ to fund the purchase of risky securities. In the case the banker exits at the end of $t$ (with probability $1-\sigma$ ), it does not have the option to issue new equity $\left.\right|^{2}$ We assume that raising equity entails a resource cost captured by a convex function of the amount raised that we specify below. This issuance cost is meant to capture in a reduced-form way the actual costs and frictions facing banks in the process of raising equity - for example, the costs of finding new investors or the frictions involved in the process of creating and selling new shares ${ }^{3}$

\subsubsection{The Banker's Problem}

The bank pays dividends only when it exits. If the exit shock realizes, the banker exits at the beginning of $t+1$, and simply waits for the risky loans to mature and then pays the net proceeds to the household. If the bank continues, it has an option to raise equity. The objective of the bank is then to maximize expected terminal payouts to the household, net of the equity transferred by the household and of the cost of equity issuance. The latter is assumed to depend on both the amount issued, $e_{t}$, and on the bank's overall scale as measured by its net worth $n_{t}$ (defined below), and is denoted $C\left(e_{t}, n_{t}\right)$.

Formally, the bank chooses state-contingent sequences $\left\{s_{t}, d_{t}, e_{t}\right\}$ to solve

$$
V_{t}\left(n_{t}\right)=\max (1-\sigma) \mathbb{E}_{t} \Lambda_{t, t+1}\left(R_{K, t+1} Q_{t} s_{t}-R_{t} d_{t}\right)+\sigma\left\{\mathbb{E}_{t} \Lambda_{t, t+1}\left[V_{t+1}\left(n_{t+1}\right)-e_{t}\right]-C\left(e_{t}, n_{t}\right)\right\}
$$

subject to

$$
Q_{t} s_{t}+R_{t-1} d_{t-1} \leq R_{K, t} Q_{t-1} s_{t-1}+d_{t}+e_{t-1}
$$

and the incentive constraint given in equation (1), where $\Lambda_{t, t+1}$ is the household's stochastic discount factor, given by the marginal rate of substitution between consumption at dates $t+1$ and $t$. Equation (2) is the bank's budget constraint, stating that the bank's expenditures (consisting of asset purchases, $Q_{t} s_{t}$, and repayment of external financing, $\left.R_{t-1} d_{t-1}\right)$ cannot exceed its revenues (stemming from payments of previous-period loans, $R_{K, t} Q_{t-1} s_{t-1}$, new external financing, $d_{t}$, and new equity, $\left.e_{t-1}\right)$. The bank's problem is also subject to balance sheet identity

$$
Q_{t} s_{t} \equiv n_{t}+d_{t}
$$

This equation is equivalent to a definition of net worth, and states that risky loans are funded by the sum of net worth, external borrowing. Combining those we obtain the law of motion of net worth:

$$
n_{t}=\left(R_{K, t}-R_{t-1}\right) Q_{t-1} s_{t-1}+R_{t-1} n_{t-1}+e_{t-1}
$$

We next guess that the value function satisfies, $V_{t}\left(n_{t}\right)=\alpha_{t} n_{t}$, where $\alpha_{t}$ is a coefficient to be

\footnotetext{
${ }^{2}$ As long as the cost of raising equity is positive, for an exiting bank it would never pay to raise equity, as the new equity would simply be transferred back to the household.

${ }^{3}$ Alternatively, the cost can be interpreted as representing a cost of lowering net dividend payouts. In the model banks pay dividends with a fixed ex ante probability $1-\sigma$, so in expectation-before the exit shock is realized— "net dividends" (dividend payouts net of new equity raised) equal $(1-\sigma) \mathbb{E}_{t}\left(R_{K, t+1} Q_{t} s_{t}-R_{t} d_{t}\right)-\sigma e_{t}$. A cost of higher $e_{t}$ is then akin to a cost of lower net dividend payouts.
} 
determined. Let

$$
\begin{aligned}
\mu_{t} & \equiv \mathbb{E}_{t}\left[\Lambda_{t, t+1}\left(1-\sigma+\sigma \alpha_{t+1}\right)\left(R_{K, t+1}-R_{t}\right)\right] \\
\nu_{t} & \equiv \mathbb{E}_{t}\left[\Lambda_{t, t+1}\left(1-\sigma+\sigma \alpha_{t+1}\right)\right] R_{t} \\
\nu_{e, t} & \equiv \mathbb{E}_{t}\left[\Lambda_{t, t+1}\left(\alpha_{t+1}-1\right)\right]
\end{aligned}
$$

Note that $\alpha_{t+1}$, capturing the value to the bank of an extra unit of net worth the following period, acts by "augmenting" banks' stochastic discount factor (SDF) so that their effective SDF is given by $\Lambda_{t, t+1}\left(1-\sigma+\sigma \alpha_{t+1}\right)$. The variable $\nu_{e, t}$ denotes the net value today of a transfer by the household that increases net worth tomorrow by one unit. In the decision to raise equity, the bank trades off the benefit $\nu_{e, t}$ against the issuing cost.

With these definitions, the problem simplifies to

$$
\alpha_{t} n_{t}=\max _{s_{t}, e_{t}} \mu_{t} Q_{t} s_{t}+\nu_{t} n_{t}+\sigma\left[\nu_{e, t} e_{t}-C\left(e_{t}, n_{t}\right)\right]
$$

subject to the incentive constraint

$$
\mu_{t} Q_{t} s_{t}+\nu_{t} n_{t}+\sigma\left[\nu_{t} e_{t}-C\left(e_{t}, n_{t}\right)\right] \geq \theta\left[Q_{t} s_{t}\right]
$$

and $(3)$. Define $x_{t} \equiv \frac{e_{t}}{n_{t}}$, and assume that the equity cost takes the following form: $C\left(e_{t}, n_{t}\right)=\frac{\kappa}{2} x_{t}^{2} n_{t}$. The first order conditions for $s_{t}$ and $x_{t}$, respectively, are as follows:

$$
\begin{aligned}
\left(1+\lambda_{t}\right) \mu_{t} & =\lambda_{t} \theta \\
\nu_{e, t} & =\kappa x_{t}
\end{aligned}
$$

where $\lambda_{t}$ represents the Lagrange multiplier on the incentive constraint.

When the constraint does not bind (i.e., when $\lambda_{t}=0$ ), we have $\mu_{t}=0$, and thus $\alpha_{t}=\nu_{t}+\frac{\sigma \kappa}{2} x_{t}^{2}$. When the constraint binds, $\mu_{t}>0$ and $\alpha_{t}=\mu_{t} \phi_{t}+\nu_{t}+\frac{\sigma \kappa}{2} x_{t}^{2}$; bank asset funding is given by the constraint at equality, $Q_{t} s_{t}=\phi_{t} n_{t}$, where $\phi_{t}$ is the maximum leverage allowed for the bank.

Rearranging the incentive constraint, maximum leverage can be expressed as follows:

$$
\phi_{t}=\frac{\nu_{t}+\frac{\sigma \kappa}{2} x_{t}^{2}}{\theta-\mu_{t}}
$$

Since bankers' problem is linear, we can easily aggregate across banks. For surviving banks, the evolution of net worth is given by (3). We assume entering bankers receive a small exogenous equity endowment, given by fraction $\xi / f$ of the value of the aggregate capital stock. Thus the law of motion of aggregate net worth is the following:

$$
N_{t}=\sigma[\left(R_{K, t}-R_{t-1}\right) \underbrace{Q_{t-1} K_{t-1}}_{=Q_{t-1} S_{t-1}}+x_{t-1} N_{t-1}+R_{t-1} N_{t-1}]+(1-\sigma) \xi Q_{t-1} K_{t-1}
$$




\subsection{Nonfinancial Firms}

There are two categories of nonfinancial firms: final goods firms and capital producers. In turn, within final goods firms we also distinguish between "capital leasing" firms and final goods producers, in order to clarify the role of bank credit used to finance capital goods purchases.

\subsubsection{Final Goods Firms}

We assume that there are two types of final goods firms: capital leasing firms and final goods producers. The first type of firm purchases capital goods from capital good producers, stores them for one period, and then rents them to final goods firms. The second type uses physical capital (rented from capital leasing firms) and labor to produce final output. Importantly, capital leasing firms have to rely on banks to obtain funding to finance purchases of capital, as explained below. In addition, final goods producers need to rely on banks to finance working capital.

In period $t-1$, a representative capital leasing firm purchases $K_{t-1}$ units of physical capital at price $Q_{t-1}$. It finances these purchases by issuing $S_{t-1}$ securities to banks which pay a statecontingent return $R_{K, t}$ in period $t$. At the beginning of period $t$, the realization of the capital quality shock $\psi_{t}$ determines the effective amount of physical capital in possession of the firm, given by $e^{\psi_{t}} K_{t-1}$. The firm rents out this capital to final goods firms at price $Z_{t}$, and then sells the undepreciated capital $(1-\delta) e^{\psi_{t}} K_{t-1}$ in the market at price $Q_{t}$. The payoff to the firm per unit of physical capital purchased is thus $e^{\psi_{t}}\left[Z_{t}+(1-\delta) Q_{t}\right]$. Given frictionless contracting between firms and banks, it follows that the return on the securities issued by the firm is given by the following (note that this equation implies that capital leasing firms make zero profits state-by-state): $R_{K, t}=e^{\psi_{t}} \frac{Z_{t}+(1-\delta) Q_{t}}{Q_{t-1}}$.

The capital quality shock $\psi_{t} \sim N\left(0, \sigma_{\psi}\right)$, which provides a source of fluctuations in returns to banks' assets, is a simple way to introduce an exogenous source of variation in the value of capital 4 These variations are enhanced by the movements in the endogenous asset price $Q_{t}$ triggered by fluctuations in $\psi_{t}$.

In the aggregate, the law of motion for capital is given by

$$
K_{t}=I_{t}+(1-\delta) e^{\psi_{t}} K_{t-1}
$$

Final goods firms produce output $Y_{t}$ using capital and labor: $Y_{t}=A_{t} F\left(e^{\psi_{t}} K_{t-1}, H_{t}\right)$, where $A_{t}$ is a shock to the total factor productivity (TFP), which is assumed to follow an AR(1) process in logs: $\log \left(A_{t}\right)=\rho_{A} \log \left(A_{t-1}\right)+\epsilon_{A, t}$ where $\epsilon_{A, t} \sim N\left(0, \sigma_{A}\right)$.

Taking into account the working capital constraint, the first order conditions for labor and for physical capital are as follows:

$$
\begin{aligned}
& A_{t} F_{1}\left(K_{t}, H_{t}\right)=Z_{t} \\
& A_{t} F_{2}\left(K_{t}, H_{t}\right)=W_{t}
\end{aligned}
$$

\footnotetext{
${ }^{4}$ This may be thought of as capturing some form of economic obsolescence. Gertler et al. (2012) provide an explicit microfoundation of fluctuations in capital quality $\psi_{t}$ based on time-varying obsolescence of intermediate goods.
} 
The credit spread is then given by the expected return on nonfinancial firm securities, $\mathbb{E}_{t}\left(R_{K, t+1}\right)$, net of the riskless rate, $R_{t}$. In our simulations below, we report an annualized credit spread, as in the data. We annualize the spread in any period $t$ by cumulating the quarterly spreads over the four subsequent periods 5

\subsubsection{Capital Producers}

Capital producers make new capital using final output and are subject to adjustment costs. They sell new capital to firms at the price $Q_{t}$. Given that households own capital producers, the objective of the capital producer is to choose $\left\{I_{t}\right\}$ to maximize the expected discounted value of profits:

$$
\max \mathbb{E}_{t} \sum_{i=0}^{\infty} \Lambda_{t, t+i}\left\{Q_{t+i} I_{t+i}-\left[1+f\left(\frac{I_{t+i}}{I_{t+i-1}}\right)\right] I_{t+i}\right\}
$$

The resulting first-order condition implies that the market of capital equals the marginal cost of investment:

$$
Q_{t}=1+f\left(\frac{I_{t}}{I_{t-1}}\right)+\frac{I_{t}}{I_{t-1}} f^{\prime}\left(\frac{I_{t}}{I_{t-1}}\right)-\mathbb{E}_{t}\left\{\Lambda_{t, t+1}\left(\frac{I_{t+1}{ }^{2}}{I_{t}}\right) f^{\prime}\left(\frac{I_{t+1}}{I_{t}}\right)\right\}
$$

\subsection{Interest rate determination}

We allow for the real interest rate to be determined exogenously such that the real interest rate follow the following stochastic process meant to capture at first pass the natural real interest rate.

$$
\log \left(R_{t}^{*}\right)=\rho_{R} \log \left(R_{t-1}^{*}\right)+\epsilon_{R, t}
$$

where $\epsilon_{R, t} \sim N\left(0, \sigma_{R}\right)$.

\subsection{Resource Constraint, Market Clearing, and Equilibrium}

The resource constraint and the balance of payments equations, respectively, are given by:

$$
\begin{aligned}
Y_{t} & =C_{t}+\left[1+f\left(\frac{I_{t}}{I_{t-1}}\right)\right] I_{t}+\sigma \frac{\kappa}{2} x_{t}^{2} N_{t}+\mathbf{T}_{t} \\
T_{t} & =R_{t-1} B_{t-1}^{*}-B_{t}^{*}
\end{aligned}
$$

where $\mathbf{T}$ stands for transfers (taxes). An equilibrium is defined as stochastic sequences for the nine quantities $Y_{t}, C_{t}, I_{t}, \mathbf{T}_{t}, B_{t}^{*}, H_{t}, K_{t}, N_{t}, x_{t}$, four prices $R_{K, t}, Q_{t}, R_{t}, W_{t}$, and five banking sector coefficients $\mu_{t}, \nu_{t}, \nu_{e, t}, \alpha_{t}, \phi_{t}$ such that households, banks, and firms solve their optimization problems,

\footnotetext{
${ }^{5}$ One consideration to note when comparing the model credit spread to its empirical counterpart is that the latter likely reflects in part expected default costs on corporate bonds, while in the model there is no explicit default by nonfinancial firms. It would be straightforward to extend the model to allow for corporate default - as in, for example, BGG (1999). However, given the finding by Gilchrist and Zakrajsek (2012) that the excess bond premium accounts for a sizable part of the variation of credit spreads, and with the goal of preserving model simplicity, we choose to abstract from default by nonfinancial firms.
} 
and all markets (for short-term debt, securities, new capital goods, final goods, and labor) clear, given exogenous stochastic sequences for $A_{t}, \psi_{t}$, and $R_{t}^{*}$.

\section{Functional Forms and Parameter Values}

In this section we describe, in turn, the functional forms and the parameter values used in the model simulations.

\subsection{Functional Forms}

The functional forms of preferences, production function, and investment adjustment cost are the following:

$$
\begin{aligned}
U\left(C_{t}, H_{t}\right) & =\frac{\left(C_{t}-\chi \frac{H_{t}^{1+\epsilon}}{1+\epsilon}\right)^{1-\gamma}-1}{1-\gamma} \\
F\left(K_{t}, H_{t}\right) & =\left(e^{\psi_{t}} K_{t-1}\right)^{\eta} H_{t}^{1-\eta} \\
f\left(\frac{I_{t}}{I_{t-1}}\right) & =\frac{\vartheta}{2}\left(\frac{I_{t}}{I_{t-1}}-1\right)^{2}
\end{aligned}
$$

The utility function, equation (20), is defined as in $\mathrm{GHH}(1988)$, which implies non-separability between consumption and leisure. This assumption eliminates the wealth effect on labor supply by making the marginal rate of substitution between consumption and labor independent of consumption. The parameter $\gamma$ is the coefficient of relative risk aversion, and $\epsilon$ determines the wage elasticity of labor supply, given by $1 / \epsilon$. The production function, equation (21), takes the Cobb-Douglas form. The coefficient $\eta$ is the elasticity of output with respect to capital. Equation (22) is the flow investment adjustment cost function, with the investment adjustment cost parameter given by $\vartheta$.

We assign values to the structural parameters of the model using a combination of calibration and econometric estimation techniques. We calibrate several preference, production, and financial sector parameters to standard values when possible, and report them in Table 1 .

We set the discount factor, $\beta$, to 0.9925 , which implies an annual real neutral rate of interest rate of $3 \%$. The following four parameters are standard values in business cycle literature: The risk aversion parameter, $\gamma$, the capital share, $\eta$, and the depreciation of capital, $\delta$, are set to $2,0.33$, and 0.025 , respectively. The reference debt to output ratio is set to 1 , which yields a ratio of external debt to GDP of $25 \%$ annually - a conservative estimate.

The values we assign to the Frisch labor supply elasticity (given by $1 / \epsilon$ ) is at the upper end of a wide range of values used in the literature. We found that these parameters are hard to identify in the estimation procedure described below. Accordingly, the Frisch labor supply elasticity is set to 8 , a value that is above the range typically found in the literature. As in Gertler and Kiyotaki (2010), this relatively high value represents an attempt to compensate for the absence of frictions such as nominal wage and price rigidities, which are typically included in quantitative DSGE models. While our framework excludes these frictions to preserve simplicity, they likely have a role in accounting for 
Table 1: Calibrated Model Parameters

\begin{tabular}{|c|c|c|c|}
\hline Parameter & Symbol & Value & Source/Target \\
\hline \multicolumn{4}{|l|}{ Conventional } \\
\hline Discount factor & $\beta$ & 0.9925 & Interest rate $(3 \%$, ann.) \\
\hline Risk aversion & $\gamma$ & 2 & Standard RBC value \\
\hline Capital share & $\eta$ & 0.33 & Standard RBC value \\
\hline Capital depreciation & $\delta$ & 0.025 & Standard RBC value \\
\hline Debt elast. of interest rate & $\varphi$ & 0.025 & Standard RBC value \\
\hline Reference debt/output ratio & $\bar{b}$ & 1 & Steady state $B / Y$ of $100 \%$ \\
\hline Labor disutility & $\chi$ & 2.22 & Steady state labor of $33 \%$ \\
\hline Inverse Frisch elast. & $\epsilon$ & $1 / 8$ & Gertler and Kiyotaki (2010) \\
\hline \multicolumn{4}{|l|}{ Financial Intermediaries } \\
\hline Survival rate & $\sigma$ & 0.95 & Exp. survival of 5 yrs \\
\hline Transfer rate & $\xi$ & 0.0001 & Small value \\
\hline Fraction divertable & $\theta$ & 0.24 & $\{$ Frequency of crises around $3 \%$, \\
\hline Cost of raising equity & $\kappa$ & 28 & Leverage of 7$\}$ \\
\hline \multicolumn{4}{|l|}{ Shock Processes } \\
\hline Persistence of interest rate & $\rho_{R}$ & 0.87 & \\
\hline $\mathrm{SD}$ of interest rate innov. (\%) & $\sigma_{R}$ & 0.14 & \\
\hline
\end{tabular}

employment and output volatility in the countries we study, hence, as Gertler and Kiyotaki (2010) do, we partly compensate for their absence by setting a relatively high elasticity of labor supply.

We then assign values to the four parameters relating to financial intermediaries: the survival rate of bankers, $\sigma$, the transfer to entering bankers, $\xi$, the fraction of assets that bankers can divert, $\theta$, and the parameter determining the cost of raising equity, $\kappa$. We calibrate $\sigma$ to 0.95 as in Gertler and Kiyotaki (2010), implying that bankers survive for about 5 years on average. This value of banks' survival rate is around the mid-point of values found in the literature.

The start-up transfer rate $\xi$ ensures that entering bankers have some funds to start operations, but otherwise plays no role. For this reason, we set it to an arbitrarily small number, equal to 0.0001 (we have verified that results are virtually unchanged if we set $\xi$ to even lower values). We then calibrate the remaining two parameters, $\theta$ and $\kappa$, to hit two targets: a leverage ratio of about 7 in the risk-adjusted steady state, and a frequency of financial crises of $3 \%$ annually. The target leverage ratio is an estimate of the average financial sector leverage for the countries in our sample 6 The target for crisis frequency is taken from Schularick and Taylor (2012). $]^{7}$ These targets yield a

\footnotetext{
${ }^{6}$ We obtain this estimate using balance sheet data for financial institutions from Haver Analytics (who in turn retrieve it from national central banks). Because the liability side of banks in the model is quite stylized-including just short-term noncontingent deposits and net worth — and does not fully capture the complexity of banks' liabilities in practice, we approximate financial-sector net worth in two different ways, that we interpret as a lower and an upper bound. First, we simply set net worth equal to the category "capital" in the balance sheet data. Second, we set it to the sum of capital and the category "other liabilities." The latter includes items with some hedging properties, for example provisions and subordinated debt. We then compute leverage as the ratio of total domestic nonfinancial assets and each of the two measures of net worth (the narrow and the broad one). We obtain a sample average across the six countries of 8.4 using the narrow definition and of 4.5 using the broad definition. Our target of 7 represents a compromise between the two extremes.

7 Schularick and Taylor (2012) report an annual probability of crises of three percent since the 1970s.
} 
Table 2: Estimated Model Parameters

\begin{tabular}{lcc}
\hline \hline Parameter & Symbol & Estimate \\
\hline Investment Adjustment Cost & $\vartheta$ & 1.371 \\
Persistence of TFP Shock & $\rho_{a}$ & 0.977 \\
SD of TFP innov. (\%) & $\sigma_{a}$ & 0.246 \\
SD of capital quality (\%) & $\sigma_{\psi}$ & 0.403 \\
\hline
\end{tabular}

value for $\theta$ of 0.24 , and for $\kappa$ of 28 .

Finally, as we have direct observations on real country interest rates, we fix the persistence and standard deviation of innovation for the interest rate shocks, $\rho_{R}$ and $\sigma_{R}$, to the real interest rate from data 8

We estimate the remaining parameters, namely, the parameter governing investment adjustment costs, $\vartheta$, and the parameters governing the evolution of technology shocks, $\rho_{a}$ and $\sigma_{a}$, and of capital quality shocks, $\sigma_{\psi}$, using a simulated method of moments. Table 2 displays parameters estimates, along with the loss function obtained at these parameter values. Our target moments are standard deviations and first order autocorrelations of output growth, consumption growth, investment growth, banking sector equity growth, and the domestic credit spread, as well as the cross-correlations of these variables with output growth 9

\section{The Real Financial (In)Stability Interest Rate in a Quan- titative Model}

In this section we characterize the financial stability interest rate in a calibrated version of our model as described above.

We first calculate the implied real interest rate in the economy that makes the constraint just binding. When the leverage constraint is slack, this implied real interest rate is a benchmark rate for financial stability: if the real rate $r$ is to increase beyond $r^{* *}$, the tightness of financial conditions would generate financial instability. In those states at which the constraint binds, conversely, we can compute the counterfactual real interest rate that makes the constraint nonbinding.

We first describe banks behavior as a function of the endogenous states in our calibrated economy. 10 Figures 1 to 3 display the policy functions for banks' net worth, leverage, the multiplier for the leverage constraint, asset prices, and investment for a range of values of the model's endogenous states. In Figure 1 the endogenous state is given by the quality of banking sector assets, $\bar{K}_{t}$, while

\footnotetext{
${ }^{8}$ We construct time series for the quarterly real gross country interest rate using the following equation: $R_{t}=$ $\left(1+i_{t}\right) E_{t}\left(\begin{array}{c}1 \\ \pi_{t+1}\end{array}\right)$, where $i_{t}$ denotes the 10-Year U.S. government bond rate, and $\pi_{t+1}$ denotes core CPI inflation rate in the U.S. We measure $E_{t}\left(\begin{array}{c}1 \\ \pi_{t+1}\end{array}\right)$ as the fitted component of a regression of $\frac{1}{\pi_{t+1}}$ onto a constant and four lags of inflation. The results are robust to using higher lags of inflation in calculating real interest rates. Data for government bond rate and core inflation are obtained from Federal Reserve Economic Data.

${ }^{9}$ For the details of the SMM estimation procedure, see Akinci and Queralto (forthcoming).

${ }^{10}$ The appendix presents the model's state variables and discusses briefly our solution methodology.
} 
Figure 1: Model Policy Functions (I): Bank Asset Quality, $\bar{K}_{t}=e^{\psi_{t}} K_{t-1}$
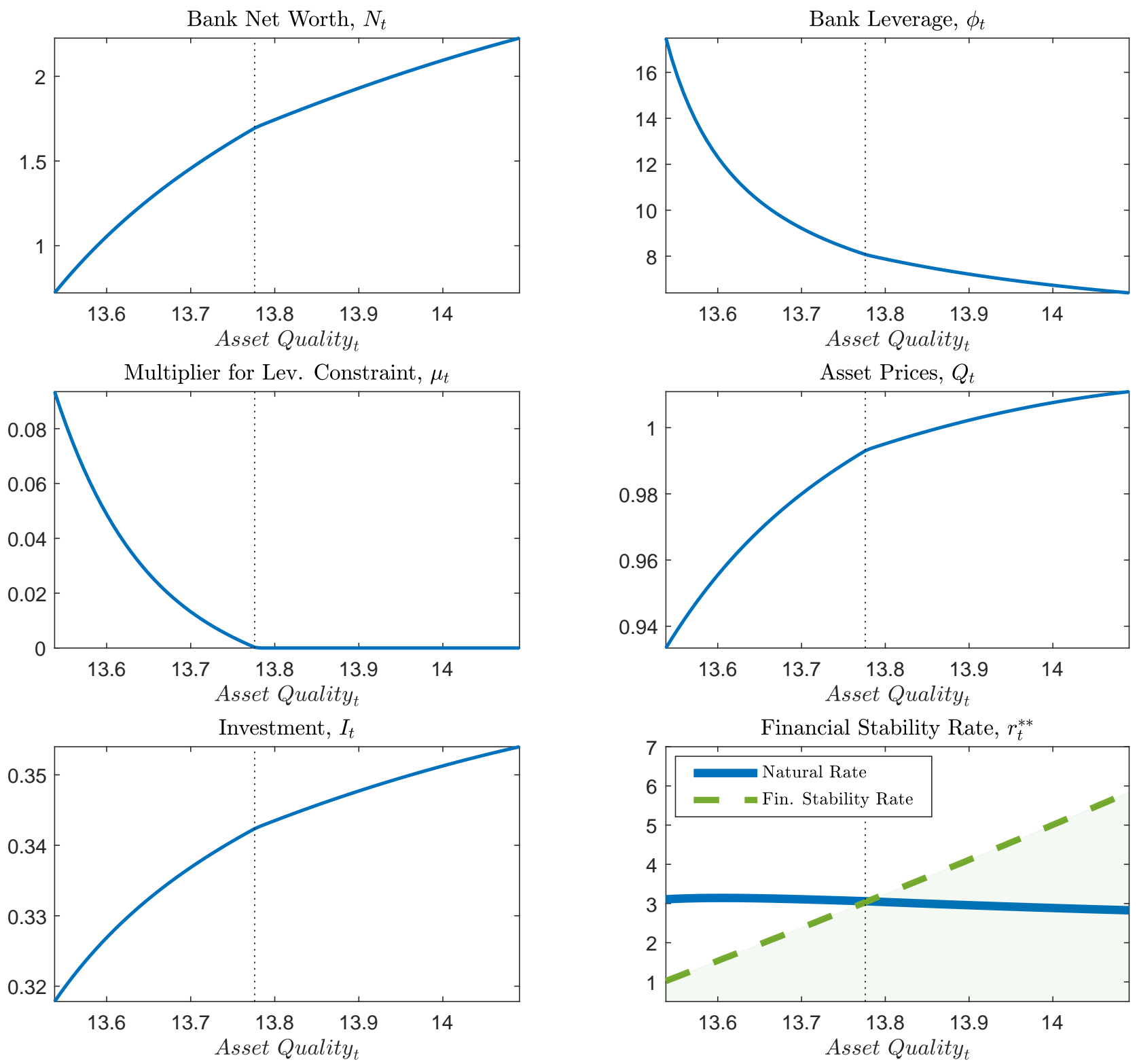

Note: Model endogenous variables as a function of state variable $\bar{K}_{t}$. All other states are kept at their risk-adjustedsteady-state value. Dotted vertical line indicates the boundary of region where the constraint binds. Financial stability rate, $\mathrm{r}^{* *}$, is meant to provide a benchmark for financial stability: if the real rate in the economy is at or above $\mathrm{r}^{* *}$, the tightness of financial conditions may generate financial instability. Accordingly, the shaded green area in the figure captures a range of values for a real at which the economy would achieve financial stability.

all other states are kept at their stochastic steady state. Similarly, in Figures 2 and 3 , the endogenous states are given by the negative of the banking sector debt, $\bar{N}_{t}$, and the foreign indebtedness, $B_{t-1}^{*}$, respectively. In each of these figures, we display the implied financial (in)stability threshold, just 
Figure 2: Model Policy Functions (II): Banking Sector Debt, $\bar{N}_{t-1}$
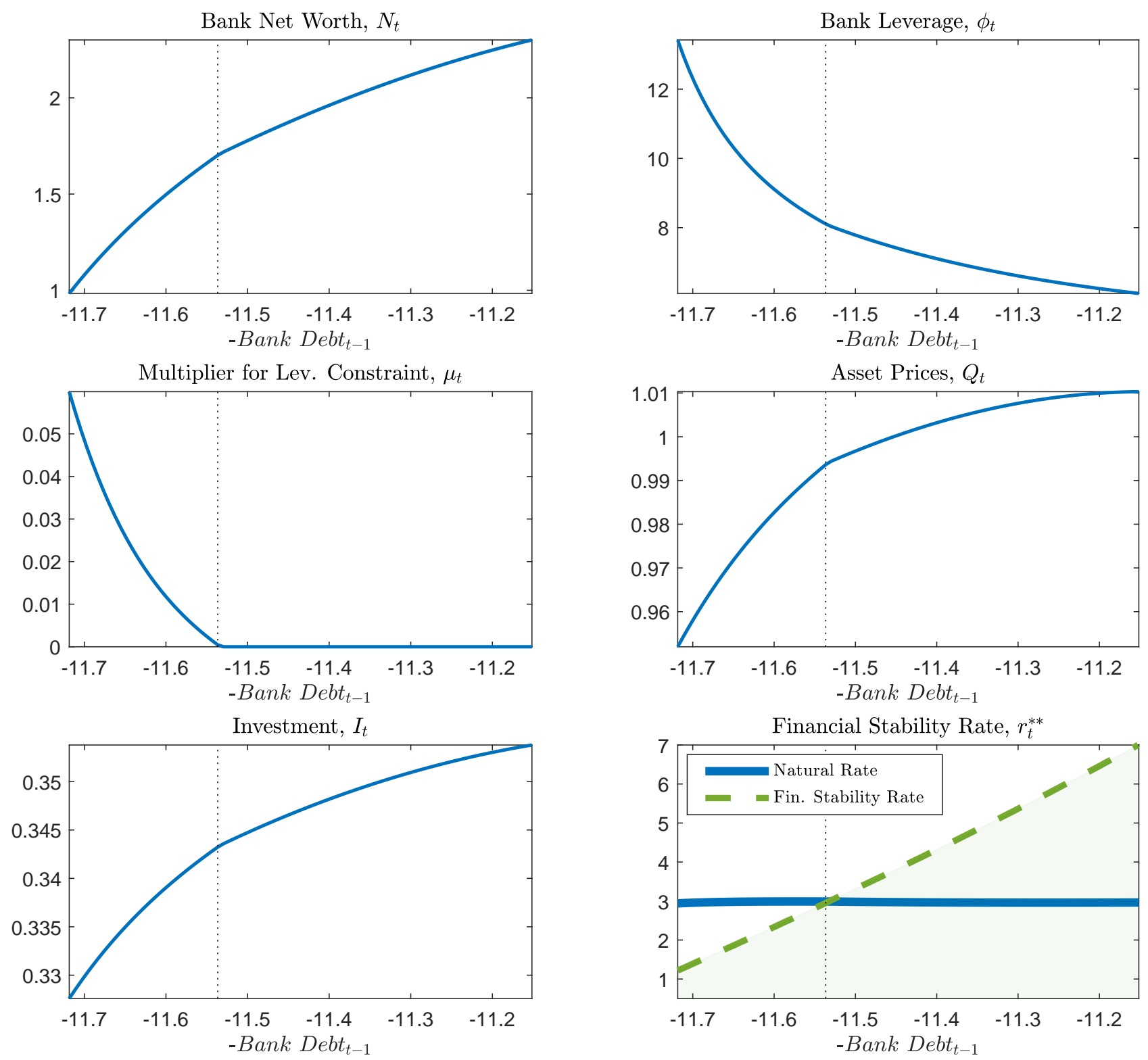

Note: Model endogenous variables as a function of state variable $\bar{N}_{t-1}$, the debt of the banking sector carried over from the previous period. All other states are kept at their risk-adjusted-steady-state value. Dotted vertical line indicates the boundary of region where the constraint binds. Financial stability rate, $\mathrm{r}^{* *}$, is meant to provide a benchmark for financial stability: if the real rate in the economy is at or above $\mathrm{r}^{* *}$, the tightness of financial conditions may generate financial instability. Accordingly, the shaded green area in the figure captures a range of values for a real at which the economy would achieve financial stability.

described, along with the natural interest rate in the model economy.

As one moves towards adverse values of endogenous state variables (given by, for example, lower 
Figure 3: Model Policy Functions (III): Foreign Debt, $B^{*}{ }_{t-1}$
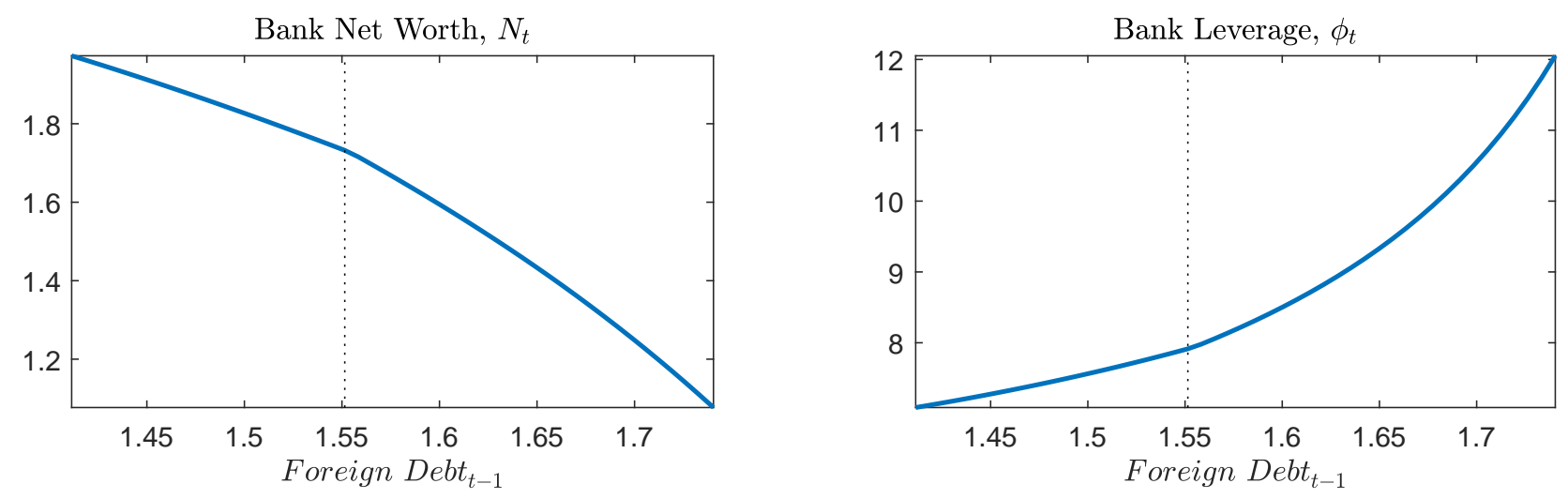

Multiplier for Lev. Constraint, $\mu_{t}$
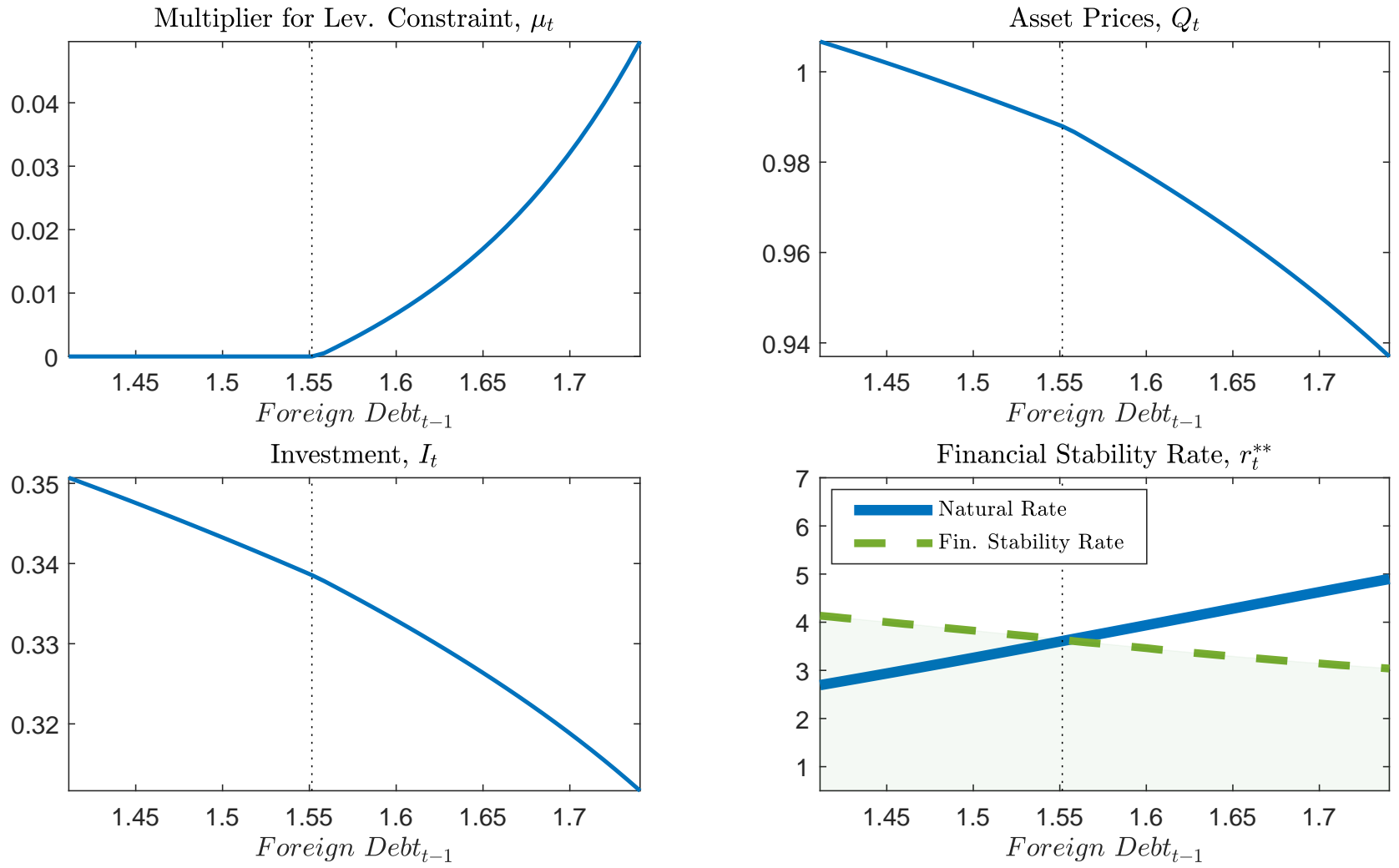

Note: Model endogenous variables as a function of state variable $B_{t-1}^{*}$, foreign debt in the previous period. All other states are kept at their risk-adjusted-steady-state value. Dotted vertical line indicates the boundary of region where the constraint binds. Financial stability rate, $\mathrm{r}^{* *}$, is meant to provide a benchmark for financial stability: if the real rate in the economy is at or above $\mathrm{r}^{* *}$, the tightness of financial conditions may generate financial instability. Accordingly, the shaded green area in the figure captures a range of values for a real at which the economy would achieve financial stability.

values of asset quality of the banking sector in Figure 1, or higher values of the banking sector debt in Figure 2, or the increased (foreign) indebtedness of the country in Figure 3), the banking sector net worth falls and eventually the leverage constraint starts binding: The multiplier for the leverage 
constraint, $\mu_{t}$, turns positive, and the declines in net worth, asset prices and investment become steeper. Along the path of deteriorating asset quality of the banking sector (or higher banking sector debt, or higher foreign indebtedness), we observe that the banking sector becomes more leveraged and the economy more vulnerable to financial instability dynamics, implying that $\mathrm{r}^{* *}$ has to fall.

Figure 4: Model Policy Functions (IV): $\bar{K}_{t} \times \bar{N}_{t-1}$

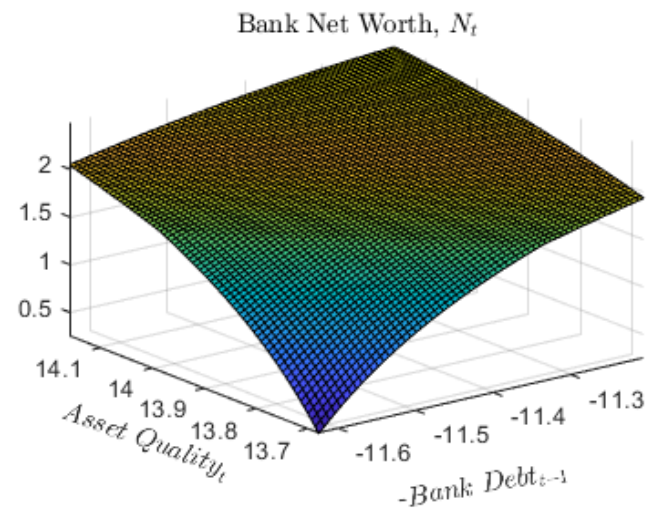

Multiplier for Lev. Constraint, $\mu_{t}$

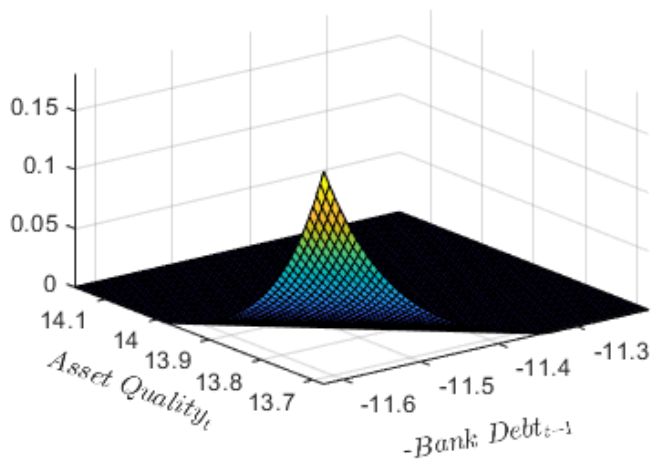

Natural Rate (ann. \%), $r_{t}^{*}$

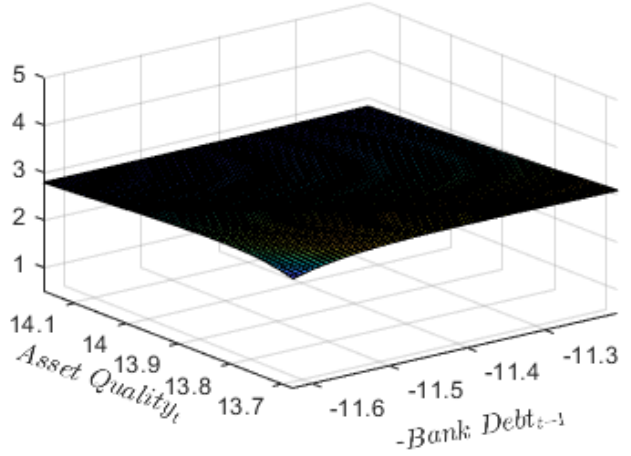

Bank Leverage, $\phi_{t}$

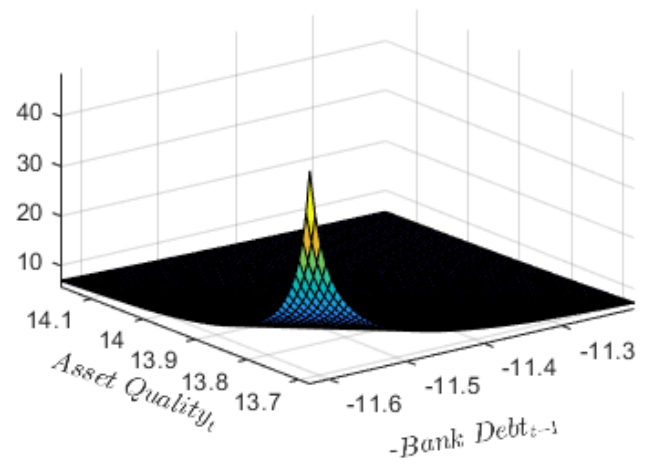

Asset Prices, $Q_{t}$

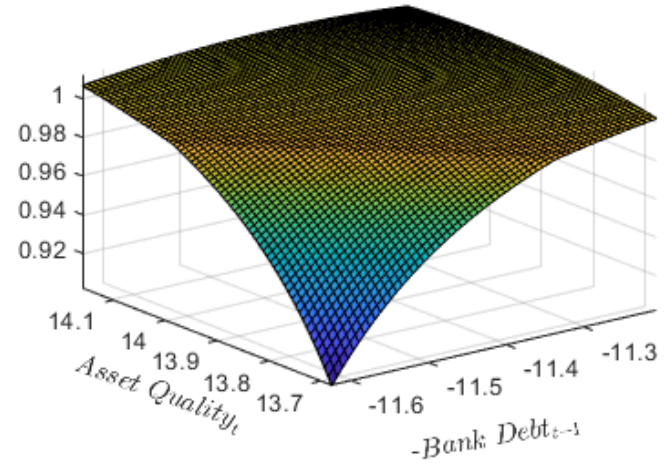

Fin. Stability Rate (ann. \%), $r_{t}^{* *}$

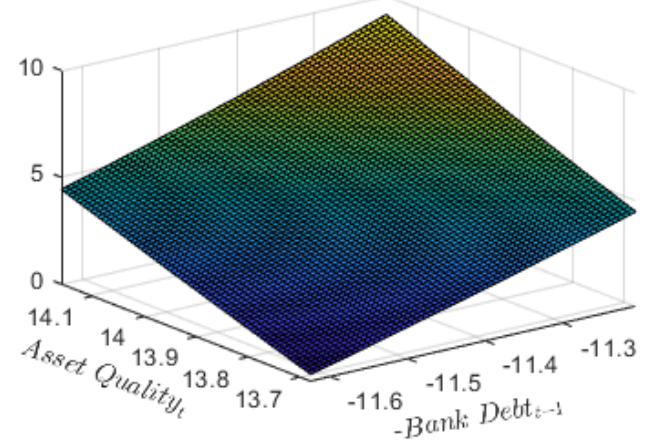

Note: Model endogenous variables as a function of quality of Bank Assets, $\bar{K}_{t}$, and the debt of the banking sector from the previous period, $\bar{N}_{t-1}$. All other states kept at risk-adjusted-steady-state value. 
Our analysis also shows that financial conditions are very interdependent in determining the level of the financial stability rate ${ }^{* *}$. Figure 4 displays the three dimensional policy functions for a given level of the banking sector debt and the quality of bank assets. The constrained region is not only characterized by very low values of asset quality or by very high values of banking sector debt, but also by a combination of relatively low values the former and relatively high values of the latter. The threshold of banking sector debt for which the constraint becomes binding, and hence the level of $\mathrm{r}^{* *}$, is a function of the level of asset quality.

Overall, increasing imbalances in the financial sector measured by an increase in leverage are accompanied by a lower threshold that could trigger financial instability events. In order to make this point, we construct a theoretical financial condition index and show how it relates to the gap between the natural and financial stability interest rates. Figure 5 illustrates the relationship between a measure of financial stresses in the model economy and the gap between the natural and financial stability interest rates. Following Groen et al. (2020), we construct a theoretical financial conditions index (FCI) using the standardized volatility of banks net worth and standardized annualized credit spread from the simulated model. In the index, volatility of banks net worth is defined as the annualized standard deviation of percentage change of banks equity. The principal component analysis on these variables yields the theoretical FCI. We normalize the FCI, so that zero indicates the average level of financial stresses in the economy while positive (negative) values are associated with levels of financial stresses in the economy higher (lower) than the average 11

The scatter plots in Figure 5 are conditioned on cases in which the constraint does not bind. Positive values of the financial condition index are associated with higher likelihood of the constraint binding. As a result, a smaller deviation of the financial stability rate from the natural rate would trigger the economy to move to the constraint region, resulting a negative relationship between the financial stress and the real rate gap. Conversely, for lower levels of financial stresses the gap between $\mathrm{r}^{* *}$ and $\mathrm{r}^{*}$ is much larger, implying that a higher interest rate hike is needed for the economy to endogenously switch to the region at which the constraint binds. The lower panels of Figure 5 displays the relationship between the components of financial conditions index and the real rate gap. As shown in the figure, credit spreads are more strongly (negatively) correlated with the real rate gap than the volatility of bank equity.

Our model economy displays strong nonlinearities consistent with the evidence from the macrofinance literature (see, for example Merton (2009), Kenny and Morgan (2011), Hubrich et al. (2013), He and Krishnamurthy (2019), or more recently Adrian et al. (2019)). Figure6 6illustrates the asymmetric relation between financial conditions index and economic activity: when financial stresses are relatively elevated, they tend to be more strongly associated with real activity than when they are relatively compressed. In particular, considering positive values of financial conditions index yields a correlation between FCI and real economic activity (calculated as year-ahead deviation of real investment from its HP trend) of about -0.53 , compared with -0.34 obtained when we consider

\footnotetext{
${ }^{11}$ The empirical financial conditions index takes the following input variables: Equity market cap index, equity cap index for the financial sector, realized equity market volatility, 10-yr government bond yield, short term government interest rate, yield curve spread, interbank spread, corporate bond spreads, JP-Morgan sovereign bond spreads, 5-yr and 10-yr government bond convenience yield spread relative to the U.S for the G10 economies (excl. the U.S.), using monthly data. Both the input variables and the financial conditions index are standardized.
} 
negative values of financial conditions index. Key to explaining the model's ability to generate this asymmetry is the occasionally binding incentive constraint: a binding constraint tends to be associated with elevated levels of financial stresses, and at the same time leads to amplified movements in real activity (via the financial accelerator).

Figure 5: Financial Conditions Index and Financial Stability Rate
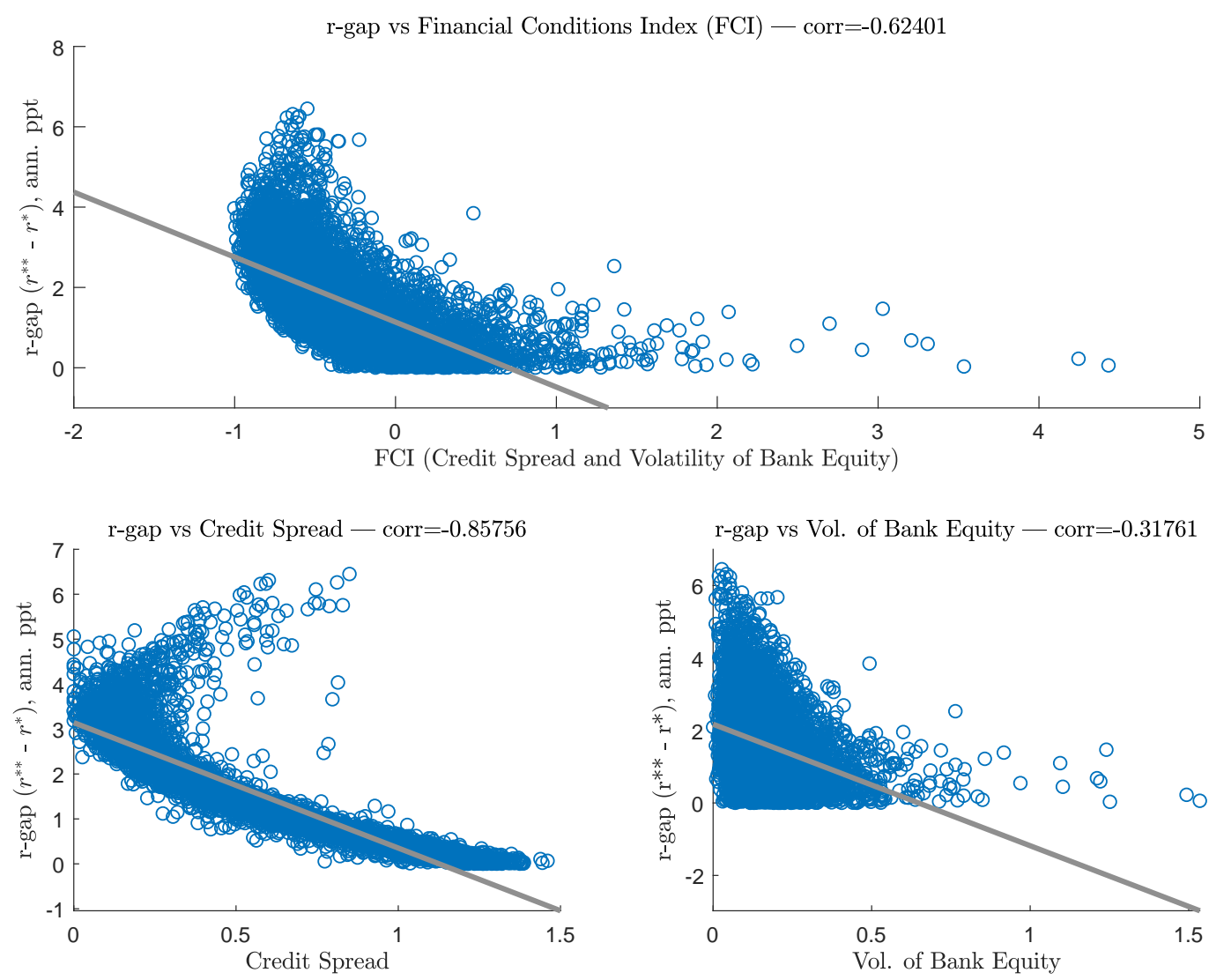

Note: r-gap is the difference between the financial stability rate and the natural rate in the model. Financial conditions index is constructed as the first principal component of the model implied corporate credit spreads and volatility of net worth, and it is standardized such that positive (negative) values of the index shown in the x-axis indicates levels of financial stresses in the economy higher (lower) than the average (as shown by zero). The scatter plot is conditioned on cases in which constraint does not bind, meaning financial stability gap is positive.

Finally, Figure 7 shows how our model produces occasional financial crisis episodes that are extreme manifestations of the asymmetric and nonlinear behavior in the model economy. We identify a crisis event as any instance in which banks' incentive constraint binds for at least four consecutive quarters and the spike in the credit spread is at least one-and-three-quarters standard deviations above average, consistent with the empirical evidence 12 We then consider a window that begins

\footnotetext{
${ }^{12}$ The first criterion regarding the crisis event selection follows the empirical evidence in Laeven and Valencia (2012) showing that actual banking crisis episodes tend to last for at least one year. The second criterion is based on our calculations in the data for each of the empirical banking crisis episodes taken from Laeven and Valencia (2012),
} 
Figure 6: Financial Conditions Index and Investment
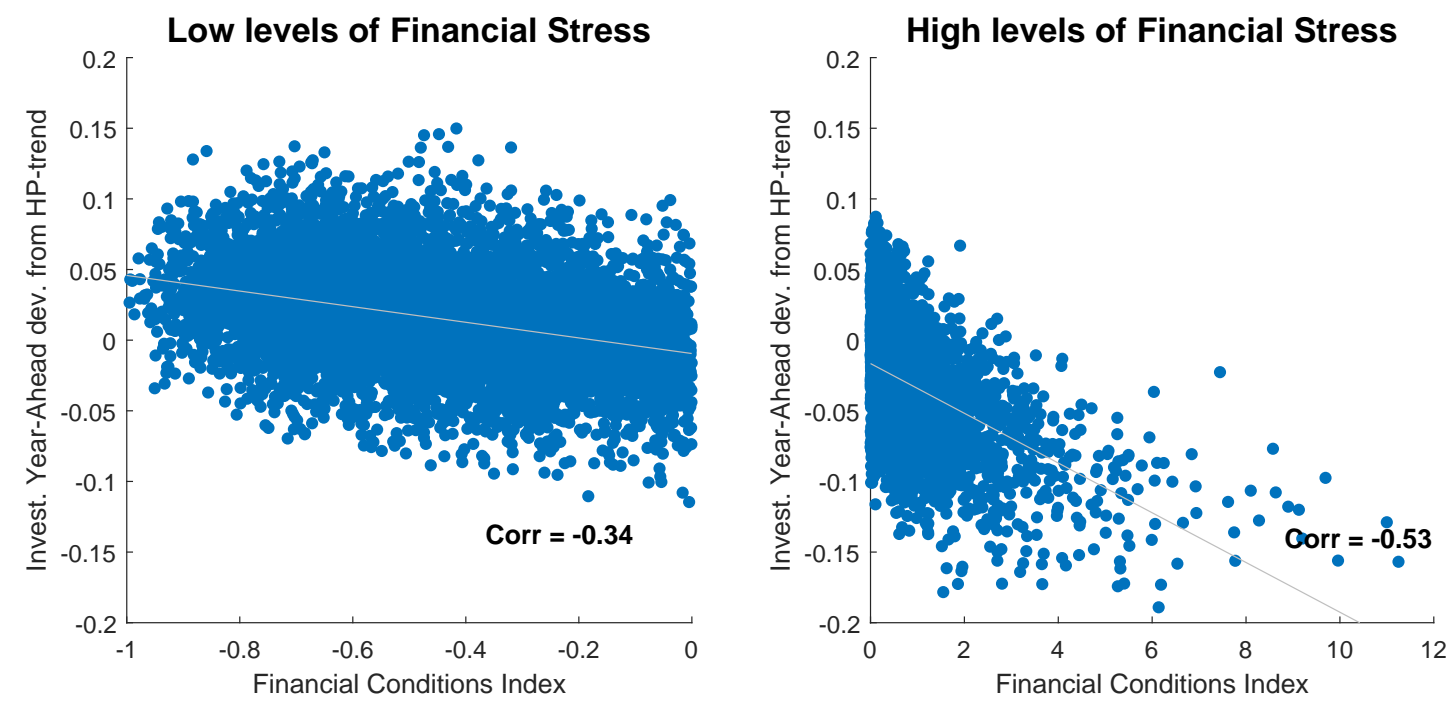

Note: The panels show the relation between Investment and financial conditions index in a 10,000-period model simulation. The vertical axis shows year-ahead average deviations of investment from its HP trend, and the horizontal axis shows financial conditions index. The left panel contains negative FCI, and the right panel contains positive FCI.

8 quarters before the crisis and ends 8 quarters after. For each variable, we compute the average period-by-period across all the crisis events that we identify. We index the quarter with the highest level of financial stress in the episode (measured as the quarter in which the credit spread is at its peak) to $t=0$, as we do in the data. We also normalize all series except credit spreads and real interest rates to their respective pre-crisis peaks.

In the quarters leading up to the crisis, bank equity (first panel, right column) deteriorates sharply, by 55 percent relative to the HP trend in about a year. These equity losses eventually put banks up against their borrowing constraints, leading credit spreads (first panel, left column) to jump sharply: the spread increases from just above 2 percentage points annually to 5.5 percentage points in only two quarters. Along the way, with a binding constraint, the financial accelerator mechanism operates, with the drops in net worth, investment, and asset prices reinforcing each other. All told, investment at the trough is about 16 percent below trend in the simulation, close to the average drop in investment in the data. Overall, our model generates financial crises consistent with the evidence: crisis periods feature severe disruption in financial intermediation, exemplified by large increases in credit spreads and sharp losses in bank equity, as well as plunges in domestic investment.

The lower right panel of Figure 7 shows the behavior of the financial stability real rate $\mathrm{r}^{* *}$. In the period preceding or following the crisis, when the constraint is not binding, $\mathrm{r}^{* *}$ is fairly constant. As soon as the crisis hits and the constraint becomes binding, $\mathrm{r}^{* *}$ drops suddenly. This behavior of

which reveal that the credit spread takes an average value around crisis episodes that is around one-and-three-quarters standard deviations above its long-run average. 
Figure 7: Average Financial Crisis: Model versus Data
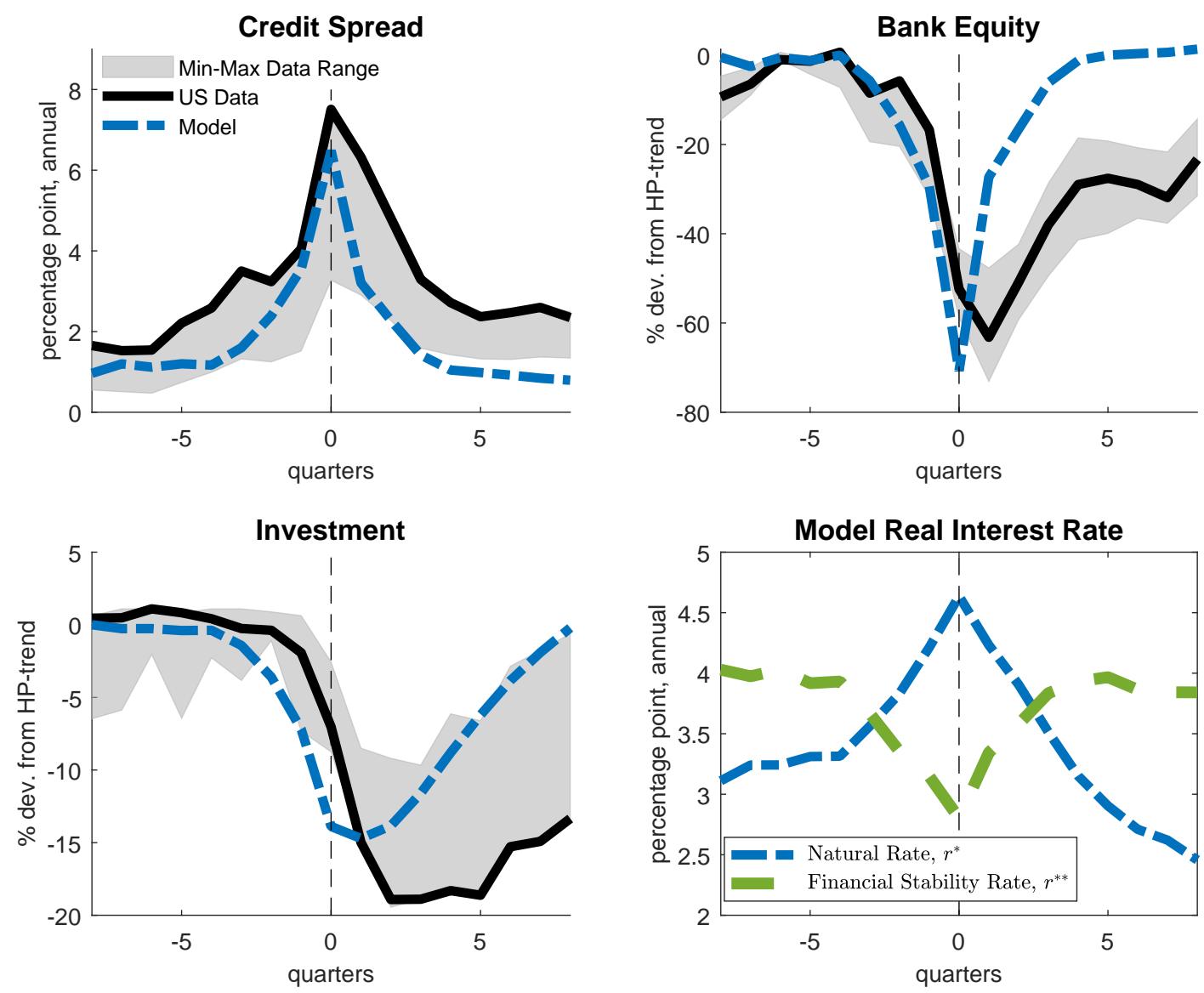

Note: A financial crisis event in the model is defined as an event in which banks' constraint binds for at least four consecutive quarters and the spike in the credit spread is at least one-and-three-quarters standard deviations above average. We simulate the economy for 10,000 periods and compute averages across identified financial crisis events. Dashed-dotted blue lines show the dynamics of macro aggregates surrounding the identified financial crisis episodes in the model. The min-max data range shows events based on 6 systemic banking crises episodes in the US, the UK, and four Euro area countries (Germany, France, Spain, Italy), with the events from data in the US shown explicitly by the black lines. Credit spreads are in percentage points. Bank equity and investment are deflated by GDP deflator, and HP detrended with a smoothing parameter 1600.

$\mathrm{r}^{* *}$ is qualitatively consistent with the evidence that central banks tend to cut interest rates quite rapidly at the onset of financial crises.

\section{Conclusion}

In this paper, we introduce the concept of financial stability real interest rate, $\mathrm{r}^{* *}$. As a vehicle to illustrate our idea, we use a macroeconomic banking model based on Gertler and Kiyotaki (2010) 
where the banking sector faces a constraint in terms of a limit on the amount of funds that it can raise. When the constraint binds the economy experiences financial instability with increasing credit spreads, declining asset prices and contraction in economy activity.

We show that as the banking sector becomes more leveraged, the financial stability interest rate becomes lower. This has implications for monetary policy, in that even relatively low levels of the real interest rate could trigger financial instability.

Our analysis is conducted within a simple real model where the natural real interest rate is exogenously determined. In future work we plan to explore the interaction between macroeconomic stability and financial stability within a richer framework in which monetary policy is endogenously specified.

\section{References}

Adrian, Tobias, Nina Boyarchenko, and Domenico Giannone, "Vulnerable growth," American Economic Review, 2019, 109 (4), 1263-89. 4

Akinci, Ozge and Albert Queralto, "Credit spreads, financial crises, and macroprudential policy," American Economic Journal: Macroeconomics, forthcoming. 1, 2, 9, 5

- and Ryan Chahrour, "Good news is bad news: Leverage cycles and sudden stops," Journal of International Economics, 2018, 114 (C), 362-375. 1]

Benigno, Gianluca, Huigang Chen, Christopher Otrok, Alessandro Rebucci, and Eric R Young, "Financial crises and macro-prudential policies," Journal of International Economics, 2013, 89 (2), 453-470. 1

Del Negro, Marco, Domenico Giannone, Marc P Giannoni, and Andrea Tambalotti, "Global trends in interest rates," Journal of International Economics, 2019, 118, 248-262. 1

Gertler, Mark and Nobuhiro Kiyotaki, "Financial intermediation and credit policy in business cycle analysis," Handbook of Monetary Economics, December 2010, 3 (C), 547-599. 2, 2.2.1, 3.1. 5

_ and _, "Banking, Liquidity, and Bank Runs in an Infinite Horizon Economy," American Economic Review, 2015, 105 (7), 2011-43. 1

- and Peter Karadi, "A model of unconventional monetary policy," Journal of Monetary Economics, 2011, 58 (1), 17 - 34. 1

_ , Nobuhiro Kiyotaki, and Albert Queralto, "Financial crises, bank risk exposure and government financial policy," Journal of Monetary Economics, 2012, 59, Supplement, S17 - S34. 4

Gilchrist, Simon and Egon Zakrajsek, "Credit Spreads and Business Cycle Fluctuations," American Economic Review, 2012, 102 (4), 1692-1720. 5

Groen, Jan, Michael Nattinger, and Adam Noble, "Measuring Global Financial Market Stresses," Technical Report, Federal Reserve Bank of New York Staff Reports 2020. 4

Haan, Wouter Den, "Parameterized Expectations," Lecture Notes, University of Amsterdam, 2007. 5]

He, Zhiguo and Arvind Krishnamurthy, "A Macroeconomic Framework for Quantifying Systemic Risk," American Economic Journal: Macroeconomics, 2019, 11 (4), 1-37. 4 
Holston, Kathryn, Thomas Laubach, and John C. Williams, "Measuring the natural rate of interest: International trends and determinants," Journal of International Economics, 2017, 108 (S1), 59-75. 1

Hubrich, Kirstin, Antonello d'Agostino, Marianna Cervena, Matteo Ciccarelli, Paolo Guarda, Markus Haavio, Philippe Jeanfils, Caterina Mendicino, Eva Ortega, Maria Teresa Valderrama et al., "Financial shocks and the macroeconomy: heterogeneity and non-linearities," ECB Occasional Paper, 2013, (143). 4

Judd, Kenneth L., Lilia Maliar, and Serguei Maliar, "Numerically stable and accurate stochastic simulation approaches for solving dynamic economic models," Quantitative Economics, 2011, 2 (2), 173-210. 5

Kenny, Geoff and Julian Morgan, "Some lessons from the financial crisis for the economic analysis," Technical Report, European Central Bank 2011. 4

Laeven, Luc and Fabian Valencia, "Systemic Banking Crises Database: An Update," IMF Working Papers 12/163, International Monetary Fund June 2012. 12

Laubach, Thomas and John C. Williams, "Measuring the Natural Rate of Interest," Review of Economics and Statistics, November 2003, 85 (4), 1063-1070. 1

Mendoza, Enrique G., "Sudden Stops, Financial Crises, and Leverage," American Economic Review, December 2010, 100 (5), 1941-66. 1

Merton, Robert M., "Observations on the Science of Finance in the Practice of Finance," 2009. 4

Schularick, Moritz and Alan M. Taylor, "Credit Booms Gone Bust: Monetary Policy, Leverage Cycles, and Financial Crises, 1870-2008," American Economic Review, 2012, 102 (2), 1029-61. 3.1. 7 


\section{Appendix: Model State Variables}

Let $\bar{K}_{t} \equiv e^{\psi_{t}} K_{t-1}$ denote the effective amount of physical capital at the beginning of period $t$ (after the capital quality shock is realized), and define $\bar{B}_{t-1} \equiv R_{t-1} B_{t-1}^{*}$ to be the stock of external debt plus interest. Let also $\bar{N}_{t-1}$ refer to the predetermined part of aggregate net worth (i.e., the component of net worth that does not depend on time- $t$ variables like $Q_{t}$ ), given by the following:

$$
\bar{N}_{t-1}=\sigma\left[x_{t-1} N_{t-1}+R_{t-1}(\underbrace{N_{t-1}-Q_{t-1} K_{t-1}}_{=-D_{t-1}})\right]+(1-\sigma) \xi Q_{t-1} K_{t-1}
$$

Note that $\bar{N}_{t-1}$ is equal to aggregate new equity issued by surviving banks $\left(\sigma x_{t-1} N_{t-1}\right)$, plus startup transfers to entering banks $\left((1-\sigma) \xi Q_{t-1} K_{t-1}\right)$, minus the total stock of debt (with interest) carried over by surviving banks $\left(\sigma R_{t-1} D_{t-1}\right)$. Given our calibration the latter term will always be large relative to the first two, so that $\bar{N}_{t-1}<0$.

Given these definitions, let $\mathcal{S}_{t}$ denote the model's aggregate state vector, given by seven variables:

$$
\mathcal{S}_{t} \equiv\left\{\bar{K}_{t},-\bar{N}_{t-1}, \bar{B}_{t-1}, R_{t-1}, I_{t-1}, R_{t}^{*}, A_{t}\right\}
$$

We use the negative of $\bar{N}_{t-1}$ so that $\mathcal{S}_{t}>0$. Our solution method relies on using parametric functions to approximate the model's one-step-ahead expectations (see Akinci and Queralto (forthcoming), Judd, Maliar and Maliar (2011) and Den Haan (2007) for details of our solution method). 